\title{
Chemical and physical properties of aloe vera (Aloe barbadensis Miller) gel stored after high hydrostatic pressure processing
}

\author{
Propriedades químicas e físicas do gel de aloe vera (Aloe barbadensis Miller) armazenado após processamento \\ sob alta pressão hidrostática
}

\author{
Karina DI SCALA ${ }^{1,2}$, Antonio VEGA-GÁLVEZ ${ }^{3,4 *}$, Kong AH-HEN ${ }^{5}$, Yissleen NUÑEZ-MANCILLA ${ }^{3}$, \\ Gipsy TABILO-MUNIZAGA ${ }^{6}$, Mario PÉREZ-WON ${ }^{3}$, Claudia GIOVAGNOLI ${ }^{3}$
}

\begin{abstract}
The aim of this study was to evaluate the influence of high hydrostatic pressure (150, 250, 350, 450, and $550 \mathrm{MPa})$, applied for 5 minutes, on antioxidant capacity, total phenolic content, color, firmness, rehydration ratio, and water holding capacity of aloe vera gel stored for 60 days at $4{ }^{\circ} \mathrm{C}$. The analyzed properties of the pressurized gel showed significant changes after the storage period. The highest value of total phenolic content was found at $550 \mathrm{MPa}$. However, a decrease in the antioxidant capacity was observed for all pressurized gel samples when compared to the control sample $(p<0.05)$. The smallest changes in product color were observed at pressure levels between 150 and $250 \mathrm{MP}$. The application of high hydrostatic pressure resulted in lower gel firmness, and the lowest value was found at $150 \mathrm{MPa}(p<0.05)$. On the other hand, the untreated sample showed a greater decrease in firmness, indicating that high pressure processing preserves this property. The application of high hydrostatic pressure exhibited modifications in the food matrix, which were evaluated in terms of rehydration ratio and water holding capacity.

Keywords: antioxidant capacity; total phenolics; quality; aloe vera.
\end{abstract}

\section{Resumo}

O objetivo deste estudo foi avaliar o efeito da aplicação de altas pressões hidrostáticas (150, 250, 350, 450 e $550 \mathrm{MPa}$ ) aplicadas durante 5 minutos sobre a atividade antioxidante, concentração de polifenóis totais, cor, firmeza, taxa de reidratação e capacidade de retenção de água do gel de aloe vera armazenado durante 60 dias a $4{ }^{\circ} \mathrm{C}$. As propriedades analisadas do gel pressurizado mostraram mudanças significativas depois de armazenadas. Para pressões de $550 \mathrm{Mpa}$, registrou-se o maior aumento de polifenóis totais. No entanto, observou-se uma diminuição da capacidade antioxidante em todas as amostras, em comparação com a amostra não tratada $(\mathrm{p}<0,05)$. As alterações de cor foram menores para pressões entre 150 e $250 \mathrm{MPa}$. A aplicação de altas pressões hidrostáticas diminuiu a firmeza do gel, registrando-se o menor valor para $150 \mathrm{MPa}(\mathrm{p}<0,05)$. Por outro lado, o tratamento sem pressão mostrou uma maior perda de firmeza, indicando que o tratamento por altas pressões conserva esta propriedade. A aplicação de altas pressões evidenciou modificações da matriz do alimento, avaliadas como taxa de reidratação e capacidade de retenção de água.

Palavras-chave: capacidade antioxidante; polifenóis totais; qualidade; aloe vera.

\section{Introduction}

Aloe vera (Aloe barbadensis Miller) is a perennial plant of the Xanthorrhoeaceae family (UNITED..., 2012). It is also placed by most sources in the Liliaceae family although it has been designated its own family, known as Aloeaceae (ESHUN; $\mathrm{HE}, 2004)$. Aloe vera is well known for its succulent leaves and the medicinal and cosmetic properties of the gel obtained from them. It is widely cultivated around the world, but has escaped from cultivation and become naturalized in the warm regions of the Mediterranean, Northern Africa, the Indian subcontinent, South America, and the Caribbean, which makes it quite difficult to correctly establish its origin. It is supposed to be native to North Africa or the Nile region in Sudan (BOZZI et al., 2007). The genus Aloe contains over 400 different species, and Aloe barbadensis, Aloe arborescens, and Aloe chinensis are the most popular. Aloe barbadensis Miller is considered the most biologically active species (BOZZI et al., 2007). Aloe latex and aloe gel are two products that can be separated from the plant (REYNOLDS; DWECK, 1999). The leaf parenchyma (aloe gel) is colorless and tasteless, and has been used particularly in the treatment of skin diseases (OKAMURA et al., 1996). The gel consists primarily of water (>98\%) and polysaccharides such as pectin, cellulose, hemicellulose, glucomannan, acemannan,

\footnotetext{
Received 6/3/2012

Accepted 4/10/2012 (005623)

Grupo de Investigación en Ingeniería de Alimentos, Facultad de Ingeniería, Universidad Nacional de Mar del Plata - UNMDP, Avda. Juan B. Justo, 4302,

Mar del Plata, Argentina

2 Consejo Nacional de Investigaciones Científicas y Técnicas - CONICET, Buenos Aires, Argentina

${ }^{3}$ Departamento de Ingeniería en Alimentos, Universidad de La Serena, Avda. Raúl Bitrán, s/n, PO Box 599, La Serena, Chile, e-mail: avegag@userena.cl

${ }^{4}$ Centro de Estudios Avanzados en Zonas Áridas - CEAZA, Universidad de La Serena, Avda. Raúl Bitrán, s/n, PO Box 599, La Serena, Chile

${ }_{5}^{5}$ Instituto de Ciencia y Tecnología de los Alimentos - ICYTAL, Universidad Austral de Chile - UACH, Avda. Julio Sarrazín, s/n, Valdivia, Chile

${ }^{6}$ Departamento de Ingeniería en Alimentos, Universidad del Bío-Bío - UBIOBIO, Avda. Andrés Bello, s/n, PO Box 447, Chillán, Chile

${ }^{*}$ Corresponding author
} 
and mannose derivates (FEMENIA et al., 1999; BOZZI et al., 2007). Aloe vera also contains potentially active constituents, such as vitamins, enzymes, minerals, sugars, lignin, saponins, salicylic acid, and amino acids (INAN et al., 2007). Due to its therapeutic and functional properties and hence its beneficial effects to humans, the use of aloe vera in the formulation of food products has steadily increased (MIRANDA et al., 2009; VEGA-GÁLVEZ et al., 2011a, b).

The use of aloe vera products often involves some type of processing such as heating, dehydration, and grinding. Unfortunately, as a result of improper processing procedures, many aloe products contain only very little or virtually no active ingredients, so that there is an imperative need to develop better methods of preservation, which would increase the shelf life of aloe vera gel simultaneously maintaining its high quality (CHANG et al., 2006; PISALKAR; JAIN; JAIN, 2011). High hydrostatic pressure (HHP) is an innovative emerging technology with great potential for optimizing the intake of nutritive phytochemicals in human food (McINERNEY et al., 2007). Food processing using HHP involves the application of pressure on the product within a range of 50 to $1000 \mathrm{MPa}$. Through this technology, it is possible to obtain safe and wholesome food that maintain all the sensory qualities (FERRARI; MARESCA; CICCARONE, 2010; VÁSQUEZ-GUTIÉRREZ et al., 2011). Some of the advantages of high-pressure processing compared to thermal processing are: reduced process time; minimum heat damage problems; retention of freshness, flavor, texture, and color; reduced ice-crystal damage; and reduced alterations in functional properties (VEGA-GÁLVEZ et al., 2011a, b). It has been reported that pressure up to $350 \mathrm{MPa}$ can be applied to plant systems without any major effect on texture and structure (KNORR, 1995). It is also generally assumed that the different published results of pressure effects on plant tissues are mainly due to product-specific pressure sensitivity and to specific stress response (SCHLÜTER et al., 2009). Therefore, in the present study the effect of high hydrostatic pressure, between 150 and $550 \mathrm{MPa}$, applied for 5 minutes, on the antioxidant capacity, total phenolic content, color, rehydration characteristics, and firmness of aloe vera gel stored for 60 days at $4{ }^{\circ} \mathrm{C}$ was evaluated.

\section{Materials and methods}

\subsection{Sample preparation and high hydrostatic pressure treatment}

Leaves of aloe vera (Aloe barbadensis Miller) were provided by the National Institute of Agricultural Research (INIA) at Intihuasi, Coquimbo, Chile. Homogenous leaves were selected according to size, ripeness, color, and freshness. Acibar (a yellow-colored liquid) was extracted by cutting the base of the leaves and allowing them to drain vertically for 1 hour. The epidermis was then separated from the gel, which was manually cut into slabs of $10 \pm 1 \mathrm{~mm}$ in thickness. All samples were kept under chilling conditions in a refrigerated room $\left(4 \pm 1^{\circ} \mathrm{C}\right)$ until high hydrostatic pressure (HHP) processing.

HHP treatment of aloe vera gel samples was carried out in a cylindrical loading container at room temperature in a 2-liter high pressure processing unit (Avure Technologies
Incorporated, Kent, WA, USA) within a cylindrical pressure chamber of $700 \mathrm{~mm}$ in length and $60 \mathrm{~mm}$ in diameter. Packaged samples were subjected to five different HHP $(150,250,350$, 450 , and $550 \mathrm{MPa}$ ) for a holding time of 5 minutes. Water was used as the pressure-transmitting medium, and pressurization was conducted working at a ramp rate of $17 \mathrm{MPa} / \mathrm{s}$ and a decompression time of less than $5 \mathrm{~s}$ at ambient temperature $\left(20 \pm 1^{\circ} \mathrm{C}\right)$. Pressurized $(150,250,350,450$, and $550 \mathrm{MPa})$ and untreated $\left(0.1 \mathrm{MPa}\right.$; control) samples were stored at $4{ }^{\circ} \mathrm{C}$ for 60 days. Quality analyses were performed after 60 days of storage on pressurized and untreated samples. All experiments were done in triplicate.

\subsection{Determination of proximate composition and analysis of sugars}

The proximate analysis was carried out according to AOAC (ASSOCIATION..., 1990). Moisture content was determined by the AOAC Official Method 934.06 using a vacuum oven (Gallenkamp, OVL570, Leicester, UK) and an analytical balance with an accuracy of $\pm 0.0001 \mathrm{~g}$ (CHYO, Jex120, Kyoto, Japan). Crude protein content was determined using the Kjeldahl method with a conversion factor of 6.25 (method 960.52). Lipid content was analyzed gravimetrically following Soxhlet extraction (method 960.39). Crude fiber was estimated by acid/alkaline hydrolysis of insoluble residues (method 962.09). Crude ash content was estimated by incineration in a muffle furnace at $550{ }^{\circ} \mathrm{C}$ (method 923.03). The available carbohydrate was estimated by difference. All measurements were done in triplicate.

Analysis of sugars (fructose and glucose) were performed chromatographically using a Thermo-Separation-Products HPLC with refractive index detector as described by Usenik, Fabčič and Štampar (2008). Measurements were done in triplicate.

\subsection{Determination of other quality parameters}

The $\mathrm{pH}$-value was measured using an EXTECH instrument microcomputer $\mathrm{pH}$-vision 246072 (Waltham, Massachusetts, USA). The level of titrimetric acidity was expressed as malic acid. Water activity $\left(\mathrm{a}_{\mathrm{w}}\right)$ was measured at $25^{\circ} \mathrm{C}$ using a water activity meter (Novasina, model TH-500, Pfäffikon, Lachen, Switzerland). All measurements were done in triplicate.

\subsection{Diphenyl-2-picrylhydrazyl (DPPH) radical scavenging assay}

Free radical scavenging activity of the samples was determined using the 2,2,-diphenyl-2picryl-hydrazyl (DPPH) method as described by Turkmen, Sari and Velioglu (2005) with some modifications. Different dilutions of the extracts of aloe vera gel were prepared in triplicate. An aliquot of $2 \mathrm{~mL}$ of $0.15 \mathrm{mM} \mathrm{DPPH}$ radical in ethanol was added to a test tube with $1 \mathrm{~mL}$ of the sample extract. The reaction mixture was vortex-mixed for $30 \mathrm{~s}$ and left to stand at room temperature in the dark for 20 minutes. The absorbance was measured at 517 $\mathrm{nm}$ using a spectrophotometer (Spectronic ${ }^{\circ} 20$ GenesysTM131, Illinois, USA). Ethanol $(80 \% \mathrm{v} / \mathrm{v})$ was used to calibrate the 
spectrophotometer. The control sample was prepared without adding any extract. All solvent and reagents were purchased from Sigma (Sigma Chemical CO., St. Louis, MO, USA). Results were expressed as percentage of inhibition of the radical DPPH, which can be related to the decrease in absorbance with respect to the control value and was determined by Equation 1:

$\%$ Inhibition $=\left[1-\left(\frac{A b s_{\text {sample }}}{A b s_{\text {control }}}\right)\right] \times 100$

where $\%$ inhibition is the total antioxidant activity and Abs is the absorbance.

\subsection{Determination of total phenolic content}

Total phenolic content (TPC) was determined colorimetrically using Folin-Ciocalteu (FC) reagent according to Chuah et al. (2008) with some modifications. An aliquot of $0.5 \mathrm{~mL}$ of aloe vera extract was transferred to a glass tube; $0.5 \mathrm{~mL}$ of FC reagent was added after 5 minutes; and $2 \mathrm{~mL}$ of $\mathrm{Na}_{2} \mathrm{CO}_{3}$ solution (200 mg.mL $\mathrm{mL}^{-1}$ ) were added and shaken. The sample was then mixed on a vortex mixer, and the reaction proceeded for 15 minutes at ambient temperature. Next, $10 \mathrm{~mL}$ of ultra-pure water were added and the formed precipitate were removed by centrifugation for 5 minutes at $4000 \mathrm{~g}$. Finally, the absorbance was measured at $725 \mathrm{~nm}$ using a spectrophotometer (Spectronic ${ }^{\circ}$ 20 GenesysTM131, Illinois, USA) and compared to a gallic acid (GA) calibration curve. Results were expressed as mg GA.100 g-1 dry matter. All reagents were purchased from Merck (Merck KGaA, Darmstadt, Germany), and all measurements were done in triplicate.

\subsection{Determination of color difference}

The color of the aloe vera gel was measured using a colorimeter (Hunter Lab, model MiniScan ${ }^{\mathrm{TM}}$ XE Plus, Reston, VA, USA) and expressed in CIELAB parameters, $L^{*}$ (whiteness or brightness), $\mathrm{a}^{\star}$ (redness/greenness), and $\mathrm{b}^{*}$ (yellowness/ blueness) under standard illumination $\mathrm{D}_{65}$ and observer angle of $10^{\circ}$. Ten replicate measurements were performed, and the results were averaged. From the coordinates $\mathrm{L}^{*}, \mathrm{a}^{*}$, and $\mathrm{b}^{*}$, the total color difference $(\Delta \mathrm{E})$ with respect to the initial color of the non-pressurized fresh sample was calculated using Equation 2:

$\Delta E=\left[\left(a^{*}-a_{0}\right)^{2}+\left(b^{*}-b_{0}\right)^{2}+\left(L^{*}-L_{0}\right)^{2}\right]^{0.5}$

where $L_{0}, a_{0}$, and $b_{0}$ are the initial color values of the nonpressurized fresh aloe vera gel.

\subsection{Determination of the rehydration indices}

The rehydration ratio (RR) and the water holding capacity (WHC) were used as rehydration indices to analyse any cellular damage caused by HHP treatment to the aloe vera gel. In this study, the gel was freeze-dried at the end of the storage period before analysis. The freeze-dried samples of aloe vera gel were placed in distilled water at $40{ }^{\circ} \mathrm{C}$ for 6 hours using a solid to liquid ratio of 1:50. The samples were then removed, drained for $3 \mathrm{~s}$, and weighed. RR was calculated according to Equation 3 and expressed as gram of water absorbed per gram dry matter. WHC was determined by centrifuging the rehydrated samples at $3500 \mathrm{~g}$ for 15 minutes at $20^{\circ} \mathrm{C}$ in tubes fitted with a centrally placed plastic mesh, which allowed water to drain freely from the sample during centrifugation. All measurements were done in triplicate. WHC was calculated from the amount of water removed according to Equation 4:

$R R=\frac{W_{\text {reh }} \times X_{\text {reh }}-W_{\text {dried }} \times X_{\text {dried }}}{W_{\text {dried }} \times\left(1-X_{\text {dried }}\right)}$

$W H C=\frac{W_{r e h} \times X_{r e h}-W_{l}}{W_{r e h} \times X_{r e h}} \times 100$

where $W_{\text {reh }}$ is the weight of the samples after the rehydration process, $X_{\text {reh }}$ is the corresponding moisture content on a wet basis, $W_{\text {dried }}$ is the weight of the sample after the freeze-drying process, $X_{\text {dried }}$ is the corresponding moisture content on a wet matter, and $W_{1}$ is the weight of the drained liquid after centrifugation.

\subsection{Determination of firmness}

Samples firmness was measured using a Texture Analyzer (Model TA-XT Plus, Surrey, UK). The puncture diameter was $3 \mathrm{~mm}$ with a travel distance of $15 \mathrm{~mm}$ and test speed of 1.5 $\mathrm{mm} / \mathrm{s}$. The maximum force needed to puncture each sample was measured. Altogether, 10 slabs were used per treatment. The mean value of firmness for each treatment was then calculated, and the results were expressed in $\mathrm{N} / \mathrm{mm}$.

\subsection{Statistical analysis}

The effect of pressure on each quality parameter was analyzed using Statgraphics ${ }^{\bullet}$ Plus 5 (Statistical Graphics Corp., Herndon, VA, USA) and analysis of variance (ANOVA). Differences among the means were analyzed using the least significant difference (LSD) test with a confidence interval of 95\%. In addition, the multiple range test (MRT) included in the statistical program was used to demonstrate the existence of homogeneous groups within each of the parameters.

\section{Results and discussion}

\subsection{Proximate composition, sugar content, and other quality parameters}

Table 1 shows the mean values and standard deviation for the chemical characteristics of the fresh aloe vera gel, which include proximate composition, sugar content, and quality parameters. The aloe vera gel analyzed presented a higher value for moisture content compared to that reported by Femenia et al. (1999). The $\mathrm{pH}$ and titrimetric acidity values were similar to the results reported in previous studies (ESHUN; HE, 2004; HERNÁNDEZ et al., 2006; MIRANDA et al., 2009). In addition, the aloe vera gel showed water activity $\left(\mathrm{a}_{\mathrm{w}}\right)$ greater than 0.98 , which means that the gel is very susceptible to attack of molds, and yields (MIRANDA et al., 2009). Regarding proteins, lipids 
Table 1. Chemical characterization of gel of aloe vera.

\begin{tabular}{lc}
\hline \multicolumn{1}{c}{ Parameters } & (g. $100 \mathrm{~g}^{-1}$ fresh gel) \\
\hline Moisture & $98.93 \pm 0.06$ \\
Protein & $0.12 \pm 0.01$ \\
Fat & $0.01 \pm 0.02$ \\
Crude fibre & $0.12 \pm 1.20$ \\
Ash & $0.16 \pm 0.02$ \\
Availabe carbohydrates & \\
& 0.66 \\
Energy (kcal.g $^{1}$ sample) & ---------- \\
$\mathrm{a}_{\mathrm{w}}{ }^{2}$ & 5.84 \\
pH $^{2}$ & $0.99 \pm 0.01$ \\
Acidity (\% malic acid) & $4.74 \pm 0.01$ \\
Glucose $^{3}$ & $0.06 \pm 0.02$ \\
Fructose $^{3}$ & $25.20 \pm 0.06$ \\
\hline
\end{tabular}

${ }^{1}$ By difference; ${ }^{2}$ Dimensionless; ${ }^{3} \mathrm{~g} \cdot 100 \mathrm{~g}^{-1}$ of dry matter.

and crude fibre, the contents were similar to those reported by Miranda et al. (2009). The ash content showed similar values to those reported by Boudreau and Beland (2006).

Table 1 also shows the contents of two of the main sugars present in the gel, namely fructose and glucose (9.3 and $25.2 \mathrm{~g} / 100 \mathrm{~g}$ dry matter, respectively). The concentration of free glucose was higher than the concentration of free fructose, which was also reported by Bozzi et al. (2007) for glucose and fructose in the commercial aloe vera powders with respective values of 11.85 and $5.3 \mathrm{~g} / 100 \mathrm{~g}$ dry matter. Femenia et al. (1999) also determined higher glucose content compared to fructose; they found $26.7 \mathrm{~g}$ glucose $/ 100 \mathrm{~g}$ dry matter in aloe vera gel compared to $0.64 \mathrm{~g}$ fructose $/ 100 \mathrm{~g}$ dry matter.

\subsection{Effect on antioxidant capacity and total phenolic content}

Figure 1 shows the antioxidant capacity of fresh and pressurized gel samples expressed as \% inhibition. Processed samples were subjected to HHP of 150, 250, 350, 450, and $550 \mathrm{MPa}$ for a holding time of 5 minutes and then stored at $4{ }^{\circ} \mathrm{C}$ for 60 days. The initial value of antioxidant capacity was $80.25 \pm 0.13 \%$. The degree of inhibition indicates the scavenging potential of the antioxidant extract, which is due to the hydrogen donating ability (BRIONES-LABARCA et al., 2011). Antioxidant compounds react with DPPH (free radicalscavenging) reducing a number of DPPH molecules equal to the number of available hydroxyl groups. Therefore, the absorption at $517 \mathrm{~nm}$ was proportional to the amount of residual (XI et al., $2011 b)$. The results showed a significant decrease in $\%$ inhibition in the pressurized gel samples treated in the range of 250-550 MPa compared to the control sample $(p<0.05)$. Samples treated at $550 \mathrm{MPa}$ showed the minimum value of antioxidant capacity $(41.43 \pm 0.13 \%$ inhibition $)$ of the gel, indicating a retention of $48 \%$ of the initial value. Nevertheless, working in the range of 150 to $250 \mathrm{MPa}$ resulted in loss of $0.1 \%$ to $9.8 \%$ of the initial antioxidant capacity of the aloe vera gel. The effect of pressure on the antioxidant capacity is not the same among the food products. Some authors have also reported that high hydrostatic pressure processing either increases or maintains the antioxidant

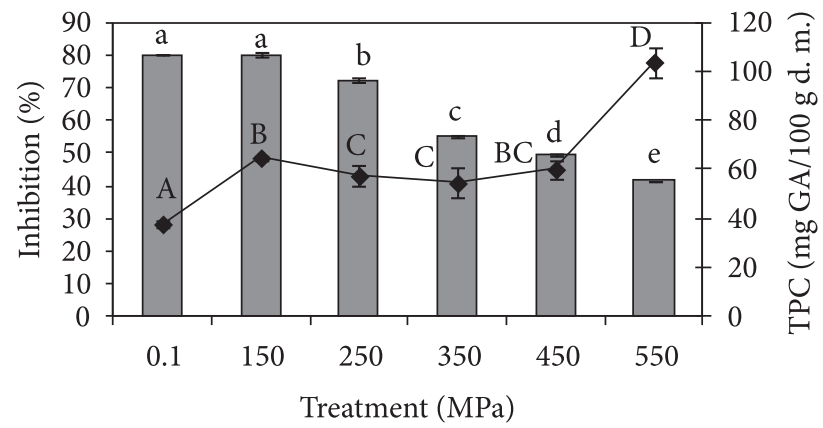

$\square$ Inhibition $(\%) \multimap$ TPC

Figure 1. Effect of high hydrostatic pressure on total phenolic content (TPC) and DPPH free radical scavenging activity (\% Inhibition) of aloe vera gel after 60 days storage. Values are mean \pm standard deviation $(\mathrm{n}=3)$. Identical letters above the bars indicate no significant difference $(p<0.05)$.

activity of foods. For example, Keenan et al. (2010) reported that the total antioxidant capacity of fruit smoothies was affected by high pressure processing (HPP). Briones-Labarca et al. (2011) also showed that HHP of apples at a high pressure level of $500 \mathrm{MPa}$ significantly affected antioxidant activity (AA) causing a decrease. However, prolonging process holding time from 2 to 10 minutes caused smaller decrease in AA. On the other hand, studies of McInerney et al. (2007) demonstrated that high pressure treatment ( 400 and $600 \mathrm{MPa}$ ) had differential effects on water soluble antioxidant activity, depending on vegetable type: broccoli HPP had no effect on AA; for carrots, only modest reduction in AA was observed, while for green beans, water soluble AA increased. Apparently exposure of plant foods to high hydrostatic pressures would change plant matrix structures. However, carrots and broccoli being firmer than green beans would probably require higher processing pressures to cause disruption of cellular structure (McINERNEY et al., 2007).

The total phenolic content (TPC) of aloe vera gel is also shown in Figure 1. An increasing trend in TPC can be observed for all treatments $(p<0.05)$. TPC changed from $54.46 \pm 7.87$ to $103.95 \pm 5.83 \mathrm{mg} \mathrm{GA} / 100 \mathrm{~g} \mathrm{~d}$. $\mathrm{m}$. in the pressurized samples compared to $37.70 \pm 1.62 \mathrm{mg} \mathrm{GA} / 100 \mathrm{~g} \mathrm{~d}$. m. in the control sample. Treatments between 150-450 MPa did not show significant difference $(\mathrm{p}<0.05)$. It is interesting to note that at $550 \mathrm{MPa}$ TPC tripled its initial value at $0.1 \mathrm{MPa}$. In view of these results, it can be concluded that HHP treatment, due to changes in aloe microstructure, produces changes in the distribution and aggregation of phenolics compounds. High pressure treatment can increase the rate of mass transfer, and enhance solvent penetration into the cells by disrupting the cellular walls and hydrophobic bonds in the cell membrane, which may lead to a high permeability. Thus, the increased of TPC observed in Figure 1 could have resulted from plant cell disruption caused by HHP leading to a higher extractability of these compounds. Based on the phase behavior theory, the solubility of these compounds increased as the pressure increased. (PRASAD et al., 2009). Further investigation related to the effects of high pressure on the distribution of phenolic 
compounds into cell walls is required to a better understanding of the role of these compounds as bioactive components.

Comparable results were previously reported in literature. Corrales et al. (2008) reported an increase in the TPC of grape by-products following HPP. Patras et al. (2009a) analyzed pressure treatment of tomato and carrot purées at 400 and $500 \mathrm{MPa}$ and found only a slight and non-significant increase in TPC. Patras et al. (2009b) also found that for blackberry purées neither high pressure (400 $\mathrm{MPa}$ ) nor thermal processing had a significant effect on the level of phenols. However, for strawberry purées, TPC were significantly higher at $600 \mathrm{MPa}$ or $500 \mathrm{MPa}$ than at $400 \mathrm{MPa}$. Prasad et al. (2009), working with longan fruit pericarp at pressures of 200-500 MPa, reported an increase in TPC from $14.6 \pm 0.2$ to $21.0 \pm 0.6 \mathrm{mg} \cdot \mathrm{g}^{-1}$ dry matter. Similarly, $\mathrm{Xi}$ et al. (2011a) showed that after extraction of green tea at high pressures at 150,250,350, and $450 \mathrm{MPa}$,TPC in green tea extracts increased from $383.40 \pm 3.14$ to $578.20 \pm 3.35 \mathrm{mg} . \mathrm{g}^{-1}$ dry matter. Barba et al. (2011) reported that after treating blueberry juice at $200 \mathrm{MPa}$ for 5 to 15 minutes there was a significant increase in TPC.

\subsection{Effect on color}

Color as a sensory characteristic is best evaluated through the determination of color difference $(\Delta \mathrm{E})$, a quantity that expresses color variation with respect to a reference value (CHEN, 2008). Figure 2 presents values of $\Delta \mathrm{E}$ determined for untreated and pressurized samples of aloe vera gel after a storage period of 60 days. The initial colorimetric parameters $L^{*}, a^{*}$, and $b^{*}$ of fresh aloe vera gel were respectively $52.00 \pm 0.06$, $-3.75 \pm 0.02$ and $18.72 \pm 0.05$ and changed respectively to $56.66 \pm 0.41,0.84 \pm 0.03$, and $10.70 \pm 0.13$ after 60 days of storage at $4{ }^{\circ} \mathrm{C}$. According to Barba et al. (2011), values of $\Delta \mathrm{E}$ can be classified analytically as not noticeable (0-0.5), slightly noticeable (0.5-1.5), noticeable (1.5-3.0), well visible (3.0-6.0), and great $(6.0-12.0)$. In the case of the aloe vera gel analyzed, the $\Delta \mathrm{E}$ value of the untreated control samples was $10.35 \pm 0.28$, which means a great color difference compared to that of the original fresh sample. The $\Delta \mathrm{E}$ values of pressurized samples varied in the range of $7.72 \pm 0.38$ to $13.31 \pm 1.36$, showing a

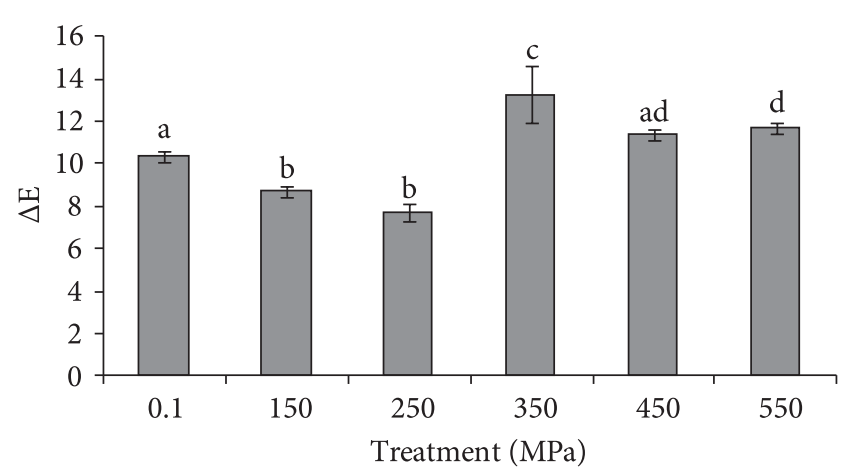

Figure 2. Effect of high hydrostatic pressure on color difference $(\Delta \mathrm{E})$ of aloe vera gel after 60 days storage. Values are mean \pm standard deviation $(\mathrm{n}=3)$. Identical letters above that bars indicate no significant difference $(p<0.05)$. minor change in color of only $16-25 \%$ at 150 and $250 \mathrm{MPa}$. However, at $350 \mathrm{MPa}$ an increase of $29 \%$ was observed, representing a greater color difference compared to that of the non-pressurized stored sample. According to ANOVA, all samples presented significant differences $(p<0.05)$. Similar results were reported by Ferrari, Maresca and Ciccarone (2010) working on pomegranate juices; these authors reported levels of pressure higher than $500 \mathrm{MPa}$ have important effects on the juice color. The color compounds of high pressure processed fruits and vegetables can change during storage due to incomplete inactivation of enzymes and microorganisms, which can result in undesired chemical reactions in the food matrix (OEY et al., 2008). Guerrero-Beltrán, Swanson and Barbosa-Cánovas (2004) demonstrated the good color stability and increased shelf life of peach purée, containing ascorbic acid, treated at $517 \mathrm{MPa}$ for 5 minutes and stored refrigerated at a temperature of $3{ }^{\circ} \mathrm{C}$. Dede, Alpas and Bayindirli, (2007), working on high hydrostatic pressure and thermal processing of carrot and tomato juices, observed that high pressure treatment of $250 \mathrm{MPa} / 35^{\circ} \mathrm{C} / 15$ minutes produced lower color difference compared to that of the fresh sample. Perera et al. (2009) also reported the effect of HPP on color of fruit products and concluded that minimal color changes were caused by HPP treatments. The majority of the studies conducted on color of fruits have demonstrated that insignificant changes occur during HPP, but visible changes in color occur after storage (AHMED; RAMASWAMY; HIREMATH, 2005).

\subsection{Effect on firmness}

High hydrostatic pressure effects on texture of food products are usually quantified by measuring hardness or firmness (OEY et al., 2008). The effect of HHP on firmness of the aloe vera gel samples after 60 days storage at $4^{\circ} \mathrm{C}$ can be observed in Figure 3. The firmness value of the non-pressurized fresh aloe vera gel was $4.00 \pm 0.67 \mathrm{~N} / \mathrm{mm}$. All pressurized samples showed a lower and significant difference in firmness when compared to non-pressurized fresh sample $(p<0.05)$. The nonpressurized stored sample had a firmness of $1.46 \pm 0.40 \mathrm{~N} / \mathrm{mm}$ $(0.1 \mathrm{MPa})$, which means a decrease by $63 \%$. However, at $150 \mathrm{MPa}$

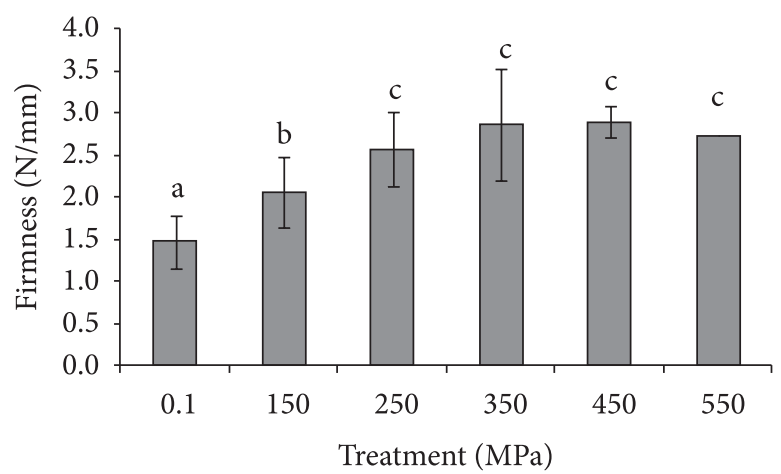

Figure 3. Effect of high hydrostatic pressure on firmness of aloe vera gel after 60 days storage. Values are mean \pm standard deviation $(n=3)$. Identical letters above the bars indicate no significant difference $(p<0.05)$. 
a decrease of only $49 \%$ was observed. At pressures between 250 to $550 \mathrm{MPa}$, no significant difference in firmness was observed among the samples $(p<0.05)$. The decrease was around $31 \%$, which was only about half of the loss of firmness compared to that of the untreated sample. These textural changes can be caused by pressure treatments resulting in physical disruption of the tissue (OEY et al., 2008; GONZÁLEZ; BARRETT, 2010). The higher decrease in firmness of the non-pressurized stored sample on the other hand may be due to microbial or enzymatic influence (VEGA-GÁLVEZ et al., 2012). The application of HHP usually influences cell wall structures, favoring permeability in cells and thus modifying the food matrix (RASTOGI; NIRANJAN, 1998). Previous studies have reported the rapid loss of firmness of some products due to HHP, such as for pears (POTHAKAMURY et al., 1997); carrot, celery, green pepper, red pepper, apple, pineapple, orange (BASAK; RAMASWAMY, 1998); green beans (KREBBERS et al., 2002), and green peas (QUAGLIA et al., 1996).

\subsection{Effect on rehydration indices}

HHP treatment can disturb cell permeability of foods enabling movement of water and metabolites into the cell. The degree of cell disruption is not only dependent on the applied pressure level but also on the type of plant cell (OEY et al., 2008). Rehydration process depends on structural changes in food products during processing (KAYMAK-ERTEKIN, 2002). Figure 4 shows the rehydration indices, RR (rehydration ratio), and WHC (water holding capacity) of the pressurized and nonpressurized samples stored for 60 days. It can be seen that RR increased with pressure increase. The non-pressurized control sample had an RR of $14.33 \pm 1.27 \mathrm{~g}$ absorbed water/g d. m., whereas the RR values of the pressurized samples changed from $16.85 \pm 3.44$ to $25.21 \pm 2.48$ g absorbed water/g d. m., which according to ANOVA, showed significant differences among the samples $(p<0.05)$. The lowest RR value among the pressurized samples was $16.85 \pm 3.44 \mathrm{~g}$ absorbed water/g d. $\mathrm{m}$. and was found at $150 \mathrm{MPa}$. This could be due to less damage of cellular structure compared to that of the higher pressure treatments, which modified the osmotic properties of the cell and lowered

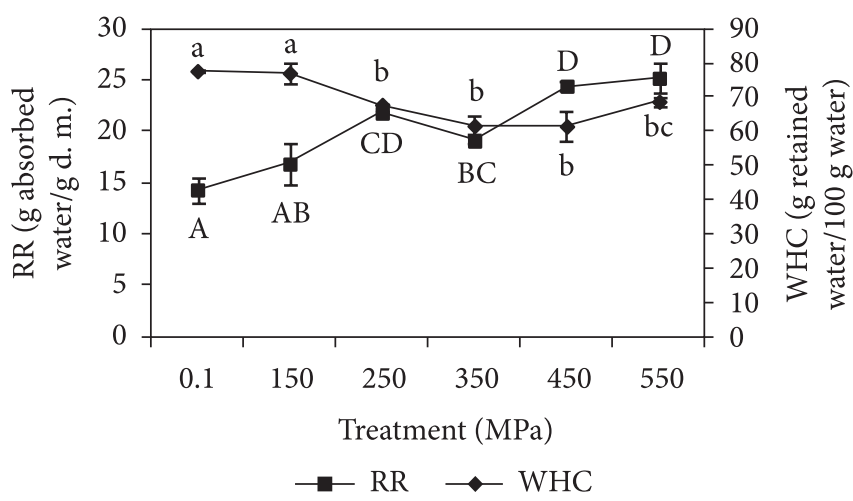

Figure 4. Effect of high hydrostatic pressure on rehydration ratio (RR) and water holding capacity (WHC) of aloe vera gel after 60 days storage. Values are mean \pm standard deviation $(n=3)$. Identical letters above the bars indicate no significant difference $(p<0.05)$. the diffusion of water through the surface during rehydration (KAYMAK-ERTEKIN, 2002).

Figure 4 shows the WHC values. This index gives an estimate of the ability of the food matrix to absorb water (MOREIRA et al., 2008). It can be seen that WHC decreased with pressure from a value of $77.10 \pm 2.50$ to $61.55 \pm 4.29 \mathrm{~g}$ retained water $/ 100 \mathrm{~g}$ water when compared to non-pressurized control sample $(77.72 \pm 0.08 \mathrm{~g}$ retained water/100 g water), indicating that the rehydrated pressurized aloe vera gel retained less water. The ANOVA test showed significant differences $(p<0.05)$. These results were associated to tissue collapse and cell damage due to high pressure processing, resulting in an increase in the rehydration ratio due to water retention in the spaces created by the damaged cells with modified internal structure. Similar results were reported in previous studies (PANDEY; RAMASWAMY; ST-GELAIS, 2000; LAKSHMANAN; PARKINSON; PIGGOTT, 2007). These changes in the structure and microstructure of foods during HHP processing are still under investigation. Finding information about precise numerical data of shape changes due to shrinkage or collapse among others is a challenge to find a correlation to process conditions and rehydration properties (AGUILERA, 2005; FERNANDO et al., 2008; MIRANDA et al., 2009).

\section{Conclusions}

Aloe vera gel subjected to HHP treatments at 150, 250, 350,450 , and $550 \mathrm{MPa}$ for 5 minutes, was affected in terms of quality during processing and storage. Antioxidant capacity, total phenolic content, color, firmness, rehydration ratio, and water holding capacity measured after 60 days storage at $4{ }^{\circ} \mathrm{C}$ showed significant changes. Total phenolic content showed an increase as pressure level increased, which is associated with cell disruption and release of these compounds. The best color retention of samples could be observed between the operating pressures of 150 and $250 \mathrm{MPa}$. Modifications in cell wall structure due to HHP also resulted in a decrease in the gel firmness as well as in its rehydration capacity meaning loss in the initial ability to retain water. These results showed that this innovative HHP technology has a potential use in the preservation of aloe vera gel quality, which would be highly beneficial for the production of a high quality ingredient.

\section{Acknowledgements}

The authors gratefully acknowledge the financial support from the Research Department at Universidad de La Serena (DIULS), Chile, and Project FONDECYT 1090228.

\section{References}

AGUILERA, J. M. Why food microstructure? Journal of Food Engineering, v. 67, n. 1-2, p. 3-11, 2005 http://dx.doi.org/10.1016/j. jfoodeng.2004.05.050

AHMED, J.; RAMASWAMY, H. S.; HIREMATH, N. The effect of high pressure treatment on rheological characteristics and colour of mango pulp. International Journal of Food Science and 
Technology, v. 40, n. 8, p. 885-895, 2005. http://dx.doi.org/10.1111/ j.1365-2621.2005.01026.x

ASSOCIATION OF OFFICIAL ANALYTICAL CHEMISTS - AOAC. Official methods of analysis of the Association of the Official Analytical Chemists. 15th ed. Arlington: AOAC, 1990.

BARBA, F. J. et al. Study of antioxidant capacity and quality parameters in an orange juice-milk beverage after high-pressure processing treatment. Food and Bioprocess Technology, v. 5, n. 6, p. 22222232, 2011. http://dx.doi.org/10.1007/s11947-011-0570-2 http:// dx.doi.org/10.1007/s11947-011-0570-2

BASAK, S.; RAMASWAMY, H. S. Effect of high pressure processing on the texture of selected fruits and vegetables. Journal of Texture Studies, v. 29, n. 5, p. 587-601, 1998. http://dx.doi. org/10.1111/j.1745-4603.1998.tb00185.x

BOUDREAU, M.; BELAND, F. An evaluation of the biological and toxicological properties of Aloe barbadensis (Miller), Aloe vera. Journal of Environmental Science and Health, v. 24, n. 1, 103154, 2006. PMid:16690538.

BOZZI, A. et al. Quality and authenticity of commercial aloe vera gel power. Food Chemistry, v. 103, n. 1, p. 22-30, 2007. http://dx.doi. org/10.1016/j.foodchem.2006.05.061

BRIONES-LABARCA, V. et al. Effects of high hydrostatic pressure (HHP) on bioaccessibility, as well as antioxidant activity, mineral and starch contents in Granny Smith apple. Food Chemistry, v. 128 , n. 2, p. 520-529, 2011. http://dx.doi.org/10.1016/j. foodchem.2011.03.074

CHANG, X. L. et al. Effect of heat treatments on the stabilities of polysaccharides substances and barbaloin in gel juice from Aoe vera Miller. Journal of Food Engineering, v. 75, n. 2, p. 245-251, 2006. http://dx.doi.org/10.1016/j.jfoodeng.2005.04.026

CHEN, X. D. Food drying fundamentals. In: CHEN, X. D.; MUJUMDAR, A. S. (Eds.). Drying Technologies in Food Processing. West Sussex: Wiley-Blackwell Publishing, 2008. cap. 1, p. 1-54.

CHUAH, A. M. et al. Effect of cooking on the antioxidant properties of coloured peppers. Food Chemistry, v. 111, n. 1, p. 20-28, 2008 http://dx.doi.org/10.1016/j.foodchem.2008.03.022

CORRALES, M. et al. Extraction of anthocyanins from grape byproducts assisted by ultrasonics, high hydrostatic pressure or pulsed electric fields: A comparison. Innovative Food Science and Emerging Technologies, v. 9, n. 1, p. 85-91, 2008. http://dx.doi. org/10.1016/j.ifset.2007.06.002

DEDE, S.; ALPAS, H.; BAYINDIRLI, A. High hydrostatic pressure treatment and storage of carrot and juices: Antioxidant activity and microbial safety. Journal of the Science of Food and Agriculture, v. 87 , n. 5, p. 773-872, 2007. http://dx.doi.org/10.1002/jsfa. 2758

ESHUN, K.; HE, Q. Aloe vera: A valuable ingredient for the food, pharmaceutical and cosmetic industries: A Review. Critical Reviews in Food Science and Nutrition, v. 44, n. 2, p. 91-96, 2004. PMid:15116756. http://dx.doi.org/10.1080/10408690490424694

FEMENIA, A. et al. Compositional features of polysaccharides from aloe vera (Aloe barbadensis Miller) plant tissues. Carbohydrate Polymers, v. 39, n. 2, p. 109-117, 1999. http://dx.doi.org/10.1016/ S0144-8617(98)00163-5

FERNANDO, W. J. N. et al. A model for constant temperature drying rates of case hardened slices of papaya and garlic. Journal of Food Engineering, v. 88, n. 2, p. 229-238, 2008. http://dx.doi. org/10.1016/j.jfoodeng.2008.02.008

FERRARI, G.; MARESCA, P.; CICCARONE, R. The application of high hydrostatic pressure for the stabilization on functional foods:
Pomegranate juice. Journal of Food Engineering, v. 100, n. 2, p. 245-253, 2010. http://dx.doi.org/10.1016/j.jfoodeng.2010.04.006

GONZÁLEZ, M. E.; BARRETT, D. M. Thermal, high pressure and electric field processing effects on plant cell membrane integrity and relevance to fruit and vegetable quality. Journal of Food Science, v. 75, n. 7, p. 121-130, 2010. PMid:21535564 PMCid:2995313. http:// dx.doi.org/10.1111/j.1750-3841.2010.01763.x

GUERRERO-BELTRÁN, J. A.; SWANSON, B. G.; BARBOSACÁNOVAS, G. V. High hydrostatic pressure processing of peach puree with and without antibrowning agents. Journal of Food Processing and Preservation, v. 28, n. 1, p. 69-85, 2004. http:// dx.doi.org/10.1111/j.1745-4549.2004.tb00538.x

HERNÁNDEZ, C. et al. Aloe vera, una planta de zonas áridas con propiedades funcionales. La Alimentación Latinoamericana, v. 266, p. 64-70, 2006.

INAN, A. et al. Effect of aloe vera on colonic anastomoses of rats. Surgical Practice, v. 11, n. 2, p. 60-65, 2007. http://dx.doi. org/10.1111/j.1744-1633.2007.00339.x

KAYMAK-ERTEKIN, F. Drying and rehydrating kinetics of green and red pepper. Journal of Food Science, v. 67, n. 1, p. 168-175, 2002. http://dx.doi.org/10.1111/j.1365-2621.2002.tb11378.x

KNORR, D. High pressure effects on plant derived foods. In: LEDWARD, D. A. et al. (Eds.). High pressure processing of foods. Loughborough: Nottingham University Press, 1995. p. 123-135. PMid:7473683.

KEENAN, D. F. et al. Effect of thermal and high hydrostatic pressure processing on antioxidant activity and colour of fruits smoothies. Innovative Food Science and Emerging Technologies, v. 11, n. 4, p. 551-556, 2010. http://dx.doi.org/10.1016/j.ifset.2010.07.003

KREBBERS, B. et al. Quality and storage-stability of high-pressure preserved green beans. Journal of Food Engineering, v. 54, n. 1, p. 27-33, 2002. http://dx.doi.org/10.1016/S0260-8774(01)00182-0

LAKSHMANAN, R.; PARKINSON, J. A.; PIGGOTT, J. R. Highpressure processing and water-holding capacity of fresh and cold-smoked salmon (Salmon salar). LWT-Food Science and Technology, v. 40, n. 3, p. 544-551, 2007. http://dx.doi.org/10.1016/j. lwt.2005.12.003

McINERNEY, J. K. et al. Effect of high pressure processing on antioxidant activity and total carotenoid content and availability in vegetables. Innovative Food Science and Emerging Technologies, v. 8, n. 4, p. 543-548, 2007. http://dx.doi.org/10.1016/j.ifset.2007.04.005

MIRANDA, M. et al. Influence of temperature on the drying kinetic, physicochemical properties, and antioxidant capacity of Aloe vera (Aloe barbadensis Miller) gel. Journal of Food Engineering, v. 91, n. 2, p. 297-304, 2009. http://dx.doi. org/10.1016/j.jfoodeng.2008.09.007

MOREIRA, R. et al. Water absorption, texture, and color kinetics of air-dried chestnut during rehydration. Journal of Food Engineering, v. 86, n. 4, p. 584-594, 2008. http://dx.doi. org/10.1016/j.jfoodeng.2007.11.012

OEY, I. et al. Does high pressure processing influence nutritional aspects of plant based food systems? Trends in Food Science and Technology, v. 19, n. 6, p. 300-308, 2008. http://dx.doi.org/10.1016/j. tifs.2007.09.002

OKAMURA, N. et al. High-performance liquid chromatographic determination of phenolic compounds in Aloe species. Journal of Chromatography A, v. 746, n. 2, p. 225-231, 1996. http://dx.doi. org/10.1016/0021-9673(96)00342-1

PANDEY, P. K.; RAMASWAMY, H. S.; ST-GELAIS, D. Water-holding capacity and gel strength of rennet curd as affected by high-pressure 
treatment of milk. Food Research International, v. 33, n. 8, p. 655-663, 2000. http://dx.doi.org/10.1016/S0963-9969(00)00110-1

PATRAS, A. et al. Effect of thermal and high pressure processing on antioxidant activity and instrumental colour of tomato and carrot purées. Innovative Food Science and Emerging Technologies, v. 10, n. 1, p. 16-22, 2009a. http://dx.doi.org/10.1016/j.ifset.2008.09.008

PATRAS, A. et al. Impact of high pressure processing on total antioxidant activity, phenolic, ascorbic acid, anthocyanin content and colour of strawberry and blackberry purées. Innovative Food Science and Emerging Technologies, v. 10, n. 3, p. 308-313, 2009 b. http://dx.doi.org/10.1016/j.ifset.2008.12.004

PERERA, N. et al. Colour and texture of apples high pressure processed in pineapple juice. Innovative Food Science and Emerging Technologies, v. 11, n. 1, p. 39-46, 2010. http://dx.doi.org/10.1016/j. ifset.2009.08.003

PISALKAR, P. S.; JAIN, N. K.; JAIN, S. K. Osmo-air drying of aloe vera gel cubes. Journal of Food Science and Technology, v. 48, n. 2, p. 183-189, 2011. PMid:21350589 PMCid:3022148. http://dx.doi. org/10.1007/s13197-010-0121-2

POTHAKAMURY, U. et al. La alta presión hidrostática: una alternativa en el procesamiento no térmico de los alimentos. Alimentaria: Revista de tecnología e hygiene de los alimentos, n. 283, p. 33-43, 1997

PRASAD, K. N. et al. Effect of high pressure extraction on the extraction yield, total phenolic content and antioxidant activity of longan fruit pericarp. Innovative Food Science and Emerging Technologies, v. 10, n. 2, p. 155-159, 2009. http://dx.doi. org/10.1016/j.ifset.2008.11.007

QUAGLIA, G. B. et al. Effect of high pressure treatment on peroxidase activity, ascorbic acid content and texture in green peas. LWT-Food Science and Technology, v. 29, n. 5-6, p. 552-555, 1996. http:// dx.doi.org/10.1006/fstl.1996.0084

RASTOGI, N. K.; NIRANJAN, K. Enhanced mass transfer during osmotic dehydration of high pressure treated pineapple. Journal of Food Science, v. 63, n. 3, p. 508-511,1998. http://dx.doi. org/10.1111/j.1365-2621.1998.tb15774.x

REYNOLDS, T.; DWECK, A. C. Aloe vera leaf gel: a review update. Journal of Ethnopharmacology, v. 68, n. 1-3, p. 3-37, 1999. http:// dx.doi.org/10.1016/S0378-8741(99)00085-9

SCHLÜTER, O. et al. Characterization of high-hydrostatic pressure effects on fresh produce using chlorophyll fluorescence image analysis. Food and Bioprocess Technology, v. 2, n. 3, p. 291-299, 2009. http://dx.doi.org/10.1007/s11947-008-0143-1

TURKMEN, N.; SARI, F.; VELIOGLU, Y. S. The effect of cooking methods on total phenolics and antioxidant activity of selected green vegetables. Food Chemistry, v. 93, n. 4, p. 713-718, 2005. http://dx.doi.org/10.1016/j.foodchem.2004.12.038

UNITED STATES. Department of Agriculture - USDA. ARS National Genetic Resources Program. Germplasm Resources Information Network - GRIN. Aloe barbadensis Miller. Beltville: National Germplasm Resources Laboratory. Disponível em: <http://www. ars-grin.gov/cgi-bin/npgs/html/taxon.pl?2518>. Acesso em: 01 mar. 2012.

USENIK, V.; FABČIČ, J.; ŠTAMPAR, F. Sugars, organic acids, phenolic composition and antioxidant activity of sweet cherry (Prunus avium L.). Food Chemistry, v. 107, n. 1, p. 185-192, 2008. http:// dx.doi.org/10.1016/j.foodchem.2007.08.004

VÁSQUEZ-GUTIÉRREZ, J. L. et al. Changes in the microstructure and location of some bioactive compounds in persimmons treated by high hydrostatic pressure. Postharvest Biology and Technology, v. 61 , n. $2-3$, p. $137-144,2011$. http://dx.doi.org/10.1016/j. postharvbio.2011.03.008

VEGA-GÁLVEZ, A. et al. Effect of high hydrostatic pressure on functional properties and quality characteristic of aloe vera gel (Aloe barbadensis Miller). Food Chemistry, v. 129, n. 3, p. 1060-1065, 2011a http://dx.doi.org/10.1016/j.foodchem.2011.05.074

VEGA-GÁLVEZ, A. et al. Effect of high hydrostatic pressure pretreatment on drying kinetic, antioxidant activity, firmness and microstructure of Aloe vera (Aloe barbadensis Miller) gel. LWTFood Science and Technology, v. 44, n. 2, p. 384-391, 2011b. http:// dx.doi.org/10.1016/j.lwt.2010.08.004

VEGA-GÁLVEZ, A. et al. Application of high hydrostatic pressure to aloe vera (Aloe barbadensis Miller) gel: Microbial inactivation and evaluation of quality parameters. Innovative Food Science and Emerging Technologies, v. 13, n. 1, p. 57-63, 2012. http://dx.doi. org/10.1016/j.ifset.2011.07.013

XI, J. et al. Ultrahigh pressure extraction as a tool to improve the antioxidant activities of green tea extracts. Food Research International, v. 44, n. 9, p. 2783-2787, 2011a. http://dx.doi. org/10.1016/j.foodres.2011.06.001

XI, J. et al.Comparison of in vitro antioxidant activities and bioactive components of green tea extracts by different extraction methods. International Journal of Pharmaceutics, v. 408, n. 1-2, p. 97-101, 2011b. PMid:21310224. http://dx.doi.org/10.1016/j. ijpharm.2011.02.002 